\title{
STUDIES ON THE OXIDASE PROPERTIES OF CERULOPLASMIN : FACTORS IN NORMAL AND WILSON'S-DISEASE SERUM AFFECTING OXIDASE ACTIVITY
}

\author{
By J. M. WALSHE
}

(From the Department of Experimental Medicine, University of Cambridge, England)

(Submitted for publication November 21, 1962; accepted March 7, 1963)

The oxidase activity of normal serum is due to the presence of the blue copper protein, ceruloplasmin. This is an $\alpha$-globulin of molecular weight 151,000 containing 8 copper atoms per molecule (1). Its physiological substrate, if any, is unknown (2), but it has a weak oxidase activity for compounds that can be oxidized to quinone or quinone imines (3). The copper atoms in the protein appear to be arranged in functional pairs, and it seems probable that a specific function exists that will be shown to depend upon the unique chemical nature of the protein, as has already been demonstrated for another copper protein, tyrosinase (4).

The concentration of ceruloplasmin in serum can be measured by estimating light absorption at $605 \mathrm{~m} \mu$ before and after the destruction of the copper-protein bond with cyanide, by immunochemical techniques, or by measuring the oxidation of paraphenylene diamine (or related compounds) either in a Warburg flask or a spectrophotometer (4). These three methods all give comparable results, although measuring different properties of the protein: the copper-protein bond, the antigenic site, and the catalytic center. The most commonly used laboratory method to determine ceruloplasmin is the estimation of the color formed during the oxidation of paraphenylene diamine, or its dimethyl derivative $(5-7)$. The result can be placed on a semiquantitative basis by comparison with those obtained by use of known amounts of purified ceruloplasmin, which within limits, gives an activity proportional to the amount of ceruloplasmin present (3). It has been suggested, however, that there are high- and lowmolecular-weight compounds present in normal plasma that inhibit the oxidase properties of ceruloplasmin; Akerfeldt (8) believed the predominant one was ascorbic acid. Compounds with sulfhydryl $(\mathrm{SH})$ groups have also been implicated
(9) and so has serum albumin (10). Richterich (11) states that ceruloplasmin oxidase activity is inhibited 10 to $25 \%$ by serum. If this is so, it becomes necessary to add ceruloplasmin to serum to obtain accurate quantitative results. Scheinberg (12) has stated that purified ceruloplasmin added to Wilson's-disease serum, with essentially zero ceruloplasmin content, has its oxidase activity potentiated $25 \%$. This discrepancy suggests that inhibitors present in normal serum may be absent in Wilson's disease, or there may be factors present in Wilson's-disease serum able to potentiate the oxidase activity of normal ceruloplasmin.

\section{METHODS}

Oxidase activity in serum was estimated by the method of Broman (7). Purified ceruloplasmin ${ }^{1}$ was prepared by the method of Curzon and Vallet (13). The preparation was kept freeze-dried, and each ampoule contained $7.2 \mathrm{mg}$ of ceruloplasmin that reconstituted in $1 \mathrm{ml}$ of water. Threefold dilution of this solution gave the following absorption characteristics: $E_{1} \mathrm{~cm}(605 \mathrm{~m} \mu)=$ 0.169 (0.006 after treatment with cyanide); $\mathrm{E}_{1} \mathrm{~cm}(280$ $\mathrm{m} \mu)=6.43$; and $[\Delta \mathrm{E}(605 \mathrm{~m} \mu)] /[\mathrm{E}(280 \mathrm{~m} \mu)]=0.025$. For assay, ceruloplasmin was made up in $0.15 \mathrm{M} \mathrm{NaCl}$ to give a final concentration in the range 20 to $30 \mathrm{mg}$ per $100 \mathrm{ml}$. The serum and ceruloplasmin solution were mixed in the proportions $3: 1,2: 2$, and $1: 3$; the oxidase activity observed for these various mixtures is expressed as a fraction of the predicted result. Thus, if the mixture gave the expected activity, the result is expressed as unity, a $20 \%$ increase in activity is recorded as 1.2 , and a similar degree of inhibition gives a result of 0.8 . The values for the ceruloplasmin concentrations in unmixed serum and ceruloplasmin are expressed as units of oxidase activity; by this technique, $\mathrm{E}_{1} \mathrm{~cm}(550 \mathrm{~m} \mu)=.800$ for $90 \mu \mathrm{g}$ ceruloplasmin (the amount in the final mixture

1 Purified normal human ceruloplasmin was the gift of Dr. L. Vallet of the Lister Institute of Preventive Medicine, Elstree, Hertfordshire, England, to whom I am most grateful. Dr. Vallet also supplied the data of absorption characteristics. 
TABLE I

Effect of addition of various whole sera on the oxidase activity of purified ceruloplasmin

\begin{tabular}{|c|c|c|c|c|c|c|}
\hline \multirow[b]{2}{*}{ Subjects } & \multirow[b]{2}{*}{ No. } & \multirow[b]{2}{*}{$\begin{array}{l}\text { Oxidase activity of } \\
\text { serum } \pm \mathrm{SE}\end{array}$} & \multicolumn{3}{|c|}{ Serum:ceruloplasmin mixtures } & \multirow{2}{*}{$\begin{array}{l}\text { Oxidase activity of } \\
\text { ceruloplasmin } \\
\text { sample } \pm \mathrm{SE}\end{array}$} \\
\hline & & & $3: 1$ Fract & $\begin{array}{l}\text { of predicted activity } \\
\qquad 2: 2\end{array}$ & $\pm \mathrm{SE} \quad 1: 3$ & \\
\hline Normal & 27 & $0.853 \pm 0.030$ & $1.030 \pm 0.014$ & $1.095 \pm 0.012$ & \multirow{4}{*}{$\begin{array}{l}1.141 \pm 0.107 \\
1.027 \pm 0.025 \\
1.193 \pm 0.034 \\
1.143\end{array}$} & $0.742 \pm 0.010$ \\
\hline Wilson's disease & 23 & $0.120 \pm 0.026$ & $0.823 \pm 0.027$ & $0.899 \pm 0.026$ & & $0.752 \pm 0.042$ \\
\hline Newborn & 6 & $0.362 \pm 0.035$ & $1.042 \pm 0.025$ & $1.126 \pm 0.033$ & & $0.654 \pm 0.026$ \\
\hline Cirrhotic & 3 & 1.220 & 1.256 & 1.176 & & 1.145 \\
\hline
\end{tabular}

when the original solution contains $30 \mathrm{mg}$ per $100 \mathrm{ml}$ ). Apoceruloplasmin was prepared by dialysis of serum or ceruloplasmin at $\mathrm{pH} 3$ (1) with a $0.125 \mathrm{M}$ potassium dihydrogen phosphate: citric acid buffer. This was followed by dialysis against a $0.15 \mathrm{M}$ solution composed of $\mathrm{NaCl}(0.10 \mathrm{M})$ and $\mathrm{NaHCO}_{3}(0.05 \mathrm{M})$. Frequent changes of buffer were made to ensure removal of all the citric acid. This procedure did not alter the mobility of ceruloplasmin on paper electrophoresis with a barbitone buffer, $\mathrm{pH} 8.4$, nor did it result in turbidity of the ceruloplasmin or of whole serum. It did, however, result in removal of $90 \%$ of the copper and over $90 \%$ of the oxidase activity. SH groups in serum were estimated according to the method of Grunert and Phillips (14).

Ultrafiltration was carried out through "Hudes" collodion membranes at a negative pressure of $75 \mathrm{~mm} \mathrm{Hg}$. At this pressure approximately $60 \%$ of the plasma water was filtered in two and one-half to three hours.

Normal serum was obtained from donors attending the Regional Blood Transfusion Center; lipemic samples were discarded. Wilson's-disease serum was obtained from patients in whom the diagnosis seemed to be beyond doubt. In one patient, C.B., the ceruloplasmin concentration was relatively high, $18 \mathrm{mg}$ per $100 \mathrm{ml}$. The diagnosis was confirmed by radiocopper studies (15). After one year of treatment with penicillamine, the ceruloplasmin level had fallen to less than $1 \mathrm{mg}$ per $100 \mathrm{ml}$. In another patient, P.V., the serum was studied on two occasions a year apart. On the first, when she was receiving treatment with penicillamine, the ceruloplasmin level was $1 \mathrm{mg}$ per $100 \mathrm{ml}$. A year later, after treatment had been discontinued for several months, the ceruloplasmin concentration had risen to $13 \mathrm{mg}$ per $100 \mathrm{ml}$. Samples of cord blood from six newborn babies were also investigated, and in addition, serum from three patients with hepatic cirrhosis.
RESULTS

Twenty-seven normal sera were studied; the mean oxidase activity was $0.853 \mathrm{U}$ (equivalent to approximately $32 \mathrm{mg}$ per $100 \mathrm{ml}$ of ceruloplasmin), with SE 0.030 . The mean value for the 27 purified ceruloplasmin samples was $0.742 \mathrm{U}$, with $\mathrm{SE}$ 0.010 . The mean of all of the three serum: ceruloplasmin mixtures showed potentiation, $1.030 \pm$ 0.014 for the $3: 1,1.095 \pm 0.012$ for the $2: 2$, and $1.141 \pm 0.017$ for the $1: 3$ mixtures, respectively (Table I). Similar results were obtained by simple dilution of serum with $0.15 \mathrm{M} \mathrm{NaCl}$ or 0.15 $\mathrm{M}$ acetate buffer, $\mathrm{pH} 4.5$ (Table II).

Sera from 23 patients with Wilson's disease were simliarly studied. The mean oxidase activity for the group was $0.120 \mathrm{U}$, with SE 0.026 . The corresponding samples of ceruloplasmin gave a mean oxidase activity of $0.752 \mathrm{U}$, with SE 0.042 . The $3: 1$ and 2:2 serum: ceruloplasmin mixtures both showed inhibition, and the $1: 3$ mixture showed slight potentiation; the figures were $0.823 \pm 0.027,0.899 \pm 0.026$, and $1.027 \pm 0.025$, respectively (Table I). The differences observed between the behavior of the normal and the Wilson's-disease sera are statistically significant for each of the three serum: ceruloplasmin dilutions, $\mathrm{p}$ being equal to or less than $0.001,0.001$, and 0.01 for each of the three dilutions.

The mean oxidase activity in the six neonatal sera was $0.361 \mathrm{U}$, with SE 0.035 . The means of

TABLE II

Effect of dilution of serum on the oxidase activity of its ceruloplasmin

\begin{tabular}{|c|c|c|c|c|c|}
\hline \multirow[b]{2}{*}{ Subjects } & \multirow[b]{2}{*}{ No. } & \multirow[b]{2}{*}{$\begin{array}{l}\text { Oxidase activity of } \\
\text { serum } \pm \mathrm{SE}\end{array}$} & \multicolumn{2}{|c|}{ Serum:diluent mixture } & \multirow[b]{2}{*}{ Diluent } \\
\hline & & & 3:1 Fractio & $\begin{array}{l}\underset{2: 2}{\text { of predicted activity }} \pm \mathrm{SE} \\
1: 3\end{array}$ & \\
\hline Normal & 7 & $1.140 \pm 0.077$ & $1.086 \pm 0.054$ & $1.111 \pm 0.027 \quad 1.091 \pm 0.048$ & $\begin{array}{l}0.15 \mathrm{M} \mathrm{Na} \mathrm{Cl} \text { or } \\
0.15 \mathrm{M} \text { Acetate buffer, } \mathrm{pH} 4.5\end{array}$ \\
\hline
\end{tabular}


TABLE III

Effect of oral penicillamine on normal serum (J.W.) and Wilson's-disease serum (P.H.)

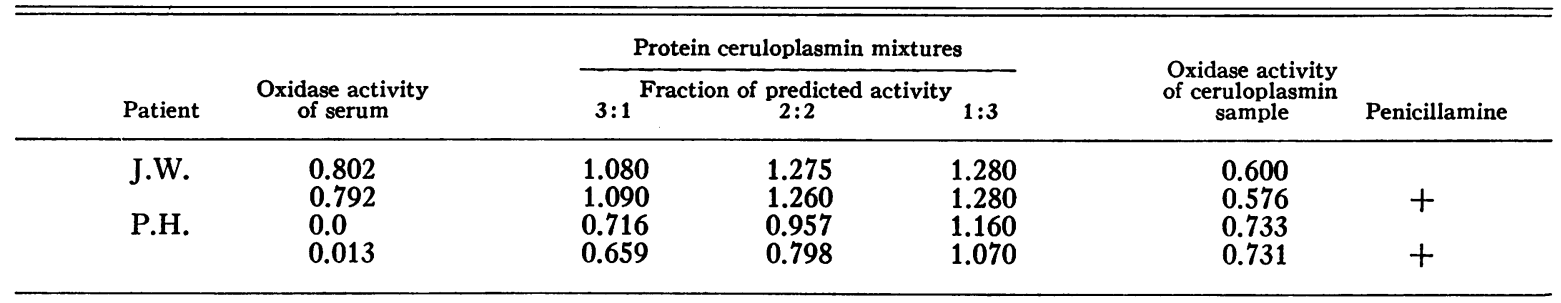

the serum: ceruloplasmin mixtures all showed potentiation similar to that observed in the normal controls, namely $1.042 \pm 0.025,1.126 \pm 0.033$, and $1.193 \pm 0.034$ (Table I). Three patients with hepatic cirrhosis also showed potentiation of oxidase activity, but in this group the maximal effect was observed in the $3: 1$ serum : ceruloplasmin mixture. For the three mixtures, the means of the results were $1.256,1.176$, and 1.145 , respectively (Table I). One normal subject and one subject with Wilson's disease were studied before and 1 hour after a dose of penicillamine $\mathrm{HCl}, 600 \mathrm{mg}$ by mouth. There was no significant change in the oxidase activity of the serum, and only in the second of the three pairs of estimations on the Wilson's-disease serum was there a significant decrease in the degree of inhibition; it is unlikely, therefore, that the penicillamine seriously influenced the reaction (Table III).

The role of high- and low-molecular-weight compounds in the apparent potentiation (normal sera) or inhibition (Wilson's-disease sera) of ceruloplasmin oxidase activity was investigated. Serum from 5 normal and 6 Wilson's-disease patients was ultrafiltered, the protein residue made up to the original volume with $0.15 \mathrm{M} \mathrm{NaCl}$, and the tests were repeated on both the protein residue and the protein-free filtrate. The results for the normal sera are given in Table IV. In the protein fraction, there was no significant change in behavior after removal of approximately $60 \%$ of the plasma water and diffusible compounds. The filtrate, which itself had no oxidase activity, strongly inhibited added ceruloplasmin, the means of the figures for the $3: 1,2: 2$, and $1: 3$ filtrate : ceruloplasmin dilutions being $0.705 \pm 0.017,0.828 \pm$ 0.036 , and $0.949 \pm 0.037$, respectively. The protein residue from the Wilson's-disease sera inhibited to approximately the same degree as whole Wilson's-disease serum. For the three standard dilutions, the results were $0.856 \pm 0.055,0.891 \pm$ 0.042 , and $1.022 \pm 0.065$, respectively. The Wilson's-disease filtrate inhibited more strongly than the whole serum or residual serum protein. The figures for the three dilutions were $0.7 \overline{4} 8 \pm 0.032$, $0.855 \pm 0.030$, and $0.964 \pm 0.024$. These results are very similar to those obtained with ultrafiltrate of normal serum.

Samples from six normal sera were treated by acid dialysis ( $\mathrm{pH} \mathrm{3)}$ to remove copper and discharge the oxidase activity of the ceruloplasmin. The untreated serum was then added to the "apo-

TABLE IV

Effect of ultrafiltration fractions (protein or filtrate) of normal and Wilson's-disease sera on the oxidase activity of purified ceruloplasmin

\begin{tabular}{|c|c|c|c|c|c|c|}
\hline \multirow[b]{2}{*}{ Samples } & \multirow{2}{*}{ No. } & \multirow{2}{*}{$\begin{array}{l}\text { Oxidase } \\
\text { activity } \\
\text { of serum } \\
\text { fraction } \\
\pm \mathrm{SE}\end{array}$} & \multicolumn{3}{|c|}{$\begin{array}{l}\text { Serum fraction: ceruloplasmin mixture fraction of } \\
\text { predicted activity } \pm S E\end{array}$} & \multirow{2}{*}{$\begin{array}{c}\text { Oxidase } \\
\text { activity } \\
\text { of cerulo } \\
\text { plasmin } \\
\pm \mathrm{SE}\end{array}$} \\
\hline & & & $3: 1$ & $2: 2$ & $1: 3$ & \\
\hline $\begin{array}{l}\text { Normal protein } \\
\text { residue }\end{array}$ & 5 & 0.899 & $1.042 \pm 0.004$ & $1.084 \pm 0.010$ & $1.136 \pm 0.018$ & 0.676 \\
\hline Normal filtrate & 5 & 0.00 & $0.705 \pm 0.017$ & $0.828 \pm 0.036$ & $0.949 \pm 0.037$ & 0.676 \\
\hline $\begin{array}{l}\text { W.D. protein } \\
\text { residue }\end{array}$ & 6 & 0.131 & $0.856 \pm 0.055$ & $0.891 \pm 0.042$ & $1.022 \pm 0.065$ & 0.671 \\
\hline W.D. filtrate & 6 & 0.002 & $0.748 \pm 0.032$ & $0.855 \pm 0.030$ & $0.964 \pm 0.024$ & 0.697 \\
\hline
\end{tabular}


TABLE V

Effect of apoceruloplasmin and "aposerum" on the oxidase activity of normal ceruloplasmin

\begin{tabular}{|c|c|c|c|c|c|c|c|}
\hline \multirow[b]{2}{*}{ Samples } & \multirow{2}{*}{ No. } & \multirow{2}{*}{$\begin{array}{l}\text { Oxidase activity of } \\
\text { sample } \pm \mathrm{SE}\end{array}$} & \multicolumn{3}{|c|}{$\begin{array}{l}\text { Serum sample: ceruloplasmin sample mixtures } \\
\text { Fraction of predicted activity } \pm \mathrm{SE}\end{array}$} & \multirow{2}{*}{$\begin{array}{l}\text { Oxidase activity } \\
\text { of cerulo- } \\
\text { plasmin } \\
\pm \mathrm{SE}\end{array}$} & \multirow{2}{*}{$\begin{array}{l}\text { Nature of } \\
\text { ceruloplasmin }\end{array}$} \\
\hline & & & $3: 1$ & $2: 2$ & $1: 3$ & & \\
\hline Normal serum & 6 & $0.842 \pm 0.015$ & $1.057 \pm 0.026$ & $1.117 \pm 0.011$ & $1.181 \pm 0.017$ & $0.819 \pm 0.020$ & Normal cp* \\
\hline Acid-dialyzed serum & 6 & $0.065 \pm 0.004$ & $0.881 \pm 0.024$ & $0.915 \pm 0.029$ & $0.942 \pm 0.021$ & $0.759 \pm 0.039$ & $\begin{array}{c}\text { Normal } \\
\text { serum }\end{array}$ \\
\hline Acid-dialyzed serum & 6 & $0.065 \pm 0.004$ & $0.740 \pm 0.015$ & $0.801 \pm 0.013$ & $0.940 \pm 0.005$ & $0.684 \pm 0.027$ & Normal cp \\
\hline $\begin{array}{l}\mathrm{Na} \mathrm{Cl}: \mathrm{Na} \mathrm{HCO}_{2-} \\
\text { dialyzed serum }\end{array}$ & 6 & $0.702 \pm 0.048$ & $1.038 \pm 0.013$ & $1.077 \pm 0.022$ & $1.122 \pm 0.026$ & $0.737 \pm 0.031$ & Normal $\mathrm{cp}$ \\
\hline Normal $\mathrm{cp}^{*}$ & 1 & 0.740 & 0.550 & 0.860 & 0.840 & 0.102 & $\begin{array}{l}\text { Acid- } \\
\text { dialyzed cp }\end{array}$ \\
\hline Normal serum & 1 & 0.706 & 0.680 & 0.860 & 0.930 & 0.062 & $\begin{array}{l}\text { Acid- } \\
\text { dialyzed } \mathrm{cp}\end{array}$ \\
\hline
\end{tabular}

$* \mathrm{cp}=$ ceruloplasmin.

serum" in the proportions previously used, and the tests were repeated. This procedure was next carried out with "aposerum" and whole ceruloplasmin and also with serum dialyzed against bicarbonate buffer only and whole ceruloplasmin. The results are given in Table V. These show that the six sera, when added to purified ceruloplasmin, potentiated the oxidase activity slighlty more than the average for the whole group, that after acid dialysis the "aposerum" inhibited the oxidase activity of the whole serum in a manner simliar to, but slightly greater than Wilson's-disease serum, that the effect of the "aposerum" on purified ceruloplasmin was also to cause inhibition, and that dialysis against the chloride: bicarbonate buffer did not result in significant loss of the oxidase properties of serum, nor cause it to inhibit purified ceruloplasmin. Finally, a preparation of purified apoceruloplasmin was mixed with untreated purified ceruloplasmin and with whole untreated serum. In both instances the apoceruloplasmin gave rise to inhibition of the oxidase activity of the mixture. In the ceruloplasmin : serum mixture, this was of the same order as in ceruloplasmin: Wilson's-disease serum mixtures, but in the ceruloplasmin:apoceruloplasmin mixture, the inhibition was in excess of the greatest found with a Wilson's-disease serum.

Determination of SH groups in both normal and Wilson's disease sera gave very low results even in patients receiving penicillamine ( $\beta$-mercaptovaline). This was to be expected, as the sera were not precipitated as soon as they were drawn and no antioxidants were added.

\section{DISCUSSION}

It has been shown that under the conditions of the ceruloplasmin assay employed, the serum of patients with Wilson's disease contains an enzyme inhibitor in the nondialyzable protein fraction that is not present in normal serum. The presence of ceruloplasmin inhibitors in normal serum has been investigated by other workers (8-10). Akerfeldt (8) believed that inhibition was caused by a lowmolecular-weight compound, probably ascorbic acid. The studies with ultrafiltrate of normal and Wilson's-disease serum described here fully support the theory that low-moleculer-weight compounds that inhibit the oxidase properties of ceruloplasmin are present in serum. Under the conditions of the test, it seems unlikely that ascorbic acid could have survived, and recent work with purified ceruloplasmin has shown that it probably has no oxidase activity towards ascorbic acid (16). As the inhibitor was present in similar concentrations in both normal and Wilson's-disease serum, its nature was not relevant to the present study. No evidence was found to support the theory that $\mathrm{SH}$ groups that may be present in plasma, either naturally occurring or after the administration of penicillamine, inhibit the oxidation of $p$-phenylenediamine by ceruloplasmin. Experiments with concentrated protein residue did not demonstrate any significant inhibitor action for ceruloplasmin by the nondiffusible fraction of normal serum, although Leach, Cohen, and Heath (10) have argued in favor of $\mathrm{SH}$ radicals on normal albumin having such an action. The concentrates of Wilson's-disease se- 
rum, however, gave rise to a significant inhibition in the oxidation of dimethyl- $p$-phenylenediamine by normal ceruloplasmin. As it is extremely unlikely that there are two abnormalities of the serum proteins in a genetically determined disease, it would seem reasonable to exclude the possibility of an abnormal albumin in Wilson's-disease serum on purely theoretical grounds. Alternative explanations are $a$ ) that a metallic ion or other low-molecular-weight compound is present in the serum and is complexed to one or more of the serum proteins, $b$ ) that an abnormal ceruloplasmin is present that inhibits the normal ceruloplasmin by substrate competition, or $c$ ) that a normal (or possibly abnormal) ceruloplasmin precursor is present that inhibits by a similar mechanism.

As all ceruloplasmin assays were conducted in the presence of disodium ethylenediaminetetraacetic acid (EDTA), it is unlikely that metallic ions were concerned with the reaction, and this probably precludes a role for the nonceruloplasmin copper in Wilson's-disease serum. The search for an abnormal ceruloplasmin in Wilson's disease, bringing this condition into line with the hemoglobinopathies and with the abnormal pseudocholinesterase (suxamethonium sensitivity) disease, has not so far been successful. Although the presence of more than one ceruloplasmin in normal serum has been established $(7,17-19)$, it has not so far been possible to demonstrate an abnormal component in the serum of patients with Wilson's disease by using either starch gel or column chromatography (20). Hitherto, all attempts to identify an abnormal ceruloplasmin in Wilson's-disease serum have depended on the oxidase activity or the blue color of the protein. However, if the liver of these patients retained the ability to synthesize the protein moiety of ceruloplasmin and either lacked the enzyme necessary to incorporate copper at the active enzyme centers, as has been suggested elsewhere (15), or produced a structurally abnormal protein lacking binding centers for the metal, the presence of an apoceruloplasmin in the serum would not be detectable by the techniques so far employed. The data that have been presented here show that purified apoceruloplasmin at concentrations in the "physiological" range inhibits both purified normal ceruloplasmin and ceruloplasmin in whole serum to the same degree as does Wilson's-disease serum. Furthermore, when the ceruloplasmin in whole serum has been rendered enzymatically inactive by removal of its copper atoms, it inhibits both purified ceruloplasmin and ceruloplasmin in whole serum to a similar extent.

This evidence does not prove that the inhibitor present in the protein fraction of Wilson's disease serum is apoceruloplasmin, but is compatible with it. Proof can only come by isolation and identification of such a protein, but as the markers, blue color and oxidase activity, are absent, this may prove extremely difficult, especially if the protein is structurally abnormal so that it cannot incorporate copper to become enzymatically active.

If this hypothesis is eventually proved, it would place the primary genetic defect in Wilson's disease not in an absence of the template necessary for the synthesis of ceruloplasmin, but in the presence of an abnormal template or the absence of an "incorporating enzyme." Such a defect has already been postulated by Osborn, Roberts, and Walshe (15), who suggested that the deficiency of a single enzyme which mediated a two-stage reaction, the concentration of copper in the liver and then its incorporation into cerulopasmin, was compatible with their radiocopper studies. These showed a delayed and defective uptake of radiocopper by the liver in Wilson's disease and confirmed the well-established inability of patients with Wilson's disease to incorporate copper into ceruloplasmin $(21,22)$.

\section{SUMMARY}

1. Purified human ceruloplasmin solution has been mixed with 27 normal sera and with 23 sera from patients with Wilson's disease in the proportions $1: 3,2: 2$, and $3: 1$; the effect on oxidase activity has been studied.

2. The normal serum: ceruloplasmin mixtures showed potentiation of oxidase activity in all proportions. The potentiation was not great, and similar apparent potentiation was observed when serum was diluted with saline.

3. The addition of ceruloplasmin to Wilson'sdisease serum resulted in inhibition of oxidase activity in the $3: 1$ and $2: 2$ mixtures and very slight potentiation in the $1: 3$ mixture. The difference from normal serum is statistically significant for all three dilutions. 
4. The serum of patients with hepatic cirrhosis of other etiologies behaved as did normal serum.

5. Protein-free filtrate of plasma from normal individuals and patients with Wilson's disease inhibited the oxidase activity of ceruloplasmin strongly. The residual protein from normal serum behaved as did whole normal serum. The residual protein from the Wilson's disease serum inhibited the oxidase activity of ceruloplasmin to the same extent as whole Wilson's-disease serum.

6. Apoceruloplasmin and whole serum from which ceruloplasmin copper had been removed by dialysis at $\mathrm{pH} 3$ both inhibited normal ceruloplasmin and ceruloplasmin in whole normal serum to the same extent as did Wilson's-disease serum.

7. The possibility is suggested that an apoceruloplasmin may be present in the serum of patients with Wilson's disease, and such a protein could not be detected by estimating either absorption at $605 \mathrm{~m} \mu$ or by determining oxidase activity.

\section{ACKNOWLEDGMENTS}

I wish to thank Mrs. J. Briggs and Miss K. Gibbs for valuable technical assistance and the many physicians who allowed me to study patients under their care.

\section{REFERENCES}

1. Holmberg, C. G., and C. B. Laurell. Investigations in serum copper. II. Isolation of the copper containing protein, and a description of some of its properties. Acta chem. scand. 1948, 2, 550.

2. Holmberg, C. G. Development of knowledge of caeruloplasmin in Wilson's Disease: Some Current Concepts. J. M. Walshe and J. N. Cumings, Eds. Oxford, Blackwell, 1962.

3. Curzon, G. Studies on the oxidase properties of caeruloplasmin in Wilson's Disease: Some Current Concepts. J. M. Walshe and J. N. Cumings, Eds. Oxford, Blackwell, 1962.

4. Scheinberg, I. H., and I. Sternlieb. Copper metabolism. Pharmacol. Rev. 1960, 12, 355.

5. Ravin, H. A. Rapid test for hepatolenticular degeneration. Lancet 1956, 1, 726.

6. Ravin, H. A. An improved colorimetric enzymatic assay of ceruloplasmin. J. Lab. clin. Med. 1961, 58, 161.
7. Broman, L. Separation and characterisation of two caeruloplasmins from human serum. Nature (Lond.) 1958, 182, 1655.

8. Akerfeldt, S. Oxidation of N,N-dimethyl-p-phenylenediamine by serum from patients with mental disease. Science 1957, 125, 117.

9. Humoller, F. L., F. A. Majka, A. J. Barak, J. D. Stevens, and J. M. Holthaus. Determination of plasma oxidase activity. Clin. Chem. 1958, 4, 1.

10. Leach, B. E., M. Cohen, R. G. Heath, and S. Martens. Studies of the role of ceruloplasmin and albumin in adrenaline metabolism. Arch. Neurol. Psychiat. (Chic.) 1956, 76, 635.

11. Richterich, R. The heterogeneity of caeruloplasmin in the newborn in Wilson's Disease: Some Current Concepts. J. M. Walshe and J. N. Cumings, Eds. Oxford, Blackwell, 1962.

12. Scheinberg, I. H. Personal communications 1960 and 1962.

13. Curzon, G., and L. Vallet. The purification of human caeruloplasmin. Biochem. J. 1960, 74, 279.

14. Grunert, R. R., and P. H. Phillips. A modification of the nitroprusside method of analysis for glutathione. Arch. Biochem. 1951, 30, 217.

15. Osborn, S. B., C. N. Roberts, and J. M. Walshe. Uptake of radiocopper by the liver. A study of patients with Wilson's disease and various control groups. Clin. Sci. 1963, 24, 13.

16. Morell, A. G., P. Aisen, and I. H. Scheinberg. Is ceruloplasmin an ascorbic acid oxidase? J. biol. Chem. 1962, 237, 3455.

17. Morell, A. G., and I. H. Scheinberg. Heterogeneity of human ceruloplasmin. Science 1960, 131, 930.

18. McAlister, R., G. M. Martin, and E. P. Benditt. Evidence for multiple caeruloplasmin components in human serum. Nature (Lond.) 1961, 190, 927.

19. Bearn, A. G., and M. D. Poulik. Heterogeneity of caeruloplasmin. Clin. chim. Acta 1962, 7, 374.

20. Huschman, S. Z., A. G. Morell, and I. H. Scheinberg. The heterogeneity of the copper-containing proteins of human plasma, ceruloplasmin. Ann. N. Y. Acad. Sci. 1961, 94, 960.

21. Bearn, A. G., and H. G. Kunkel. Metabolic studies in Wilson's disease using $\mathrm{Cu}^{\text {es }}$. J. Lab. clin. Med. 1955, 45, 623.

22. Sternlieb, I., A. G. Morell, C. D. Bauer, B. Comber, S. De Bobes-Sternberg, and I. H. Scheinberg. Detection of the heterozygous carrier of the Wilson's disease gene. J. clin. Invest. 1961, 40, 707. 